$1-1-1906$

\title{
Occurrence of barium in the Ohio Valley brines and its relation to stock poisoning
}

Charles D. Howard

Follow this and additional works at: https://researchrepository.wvu.edu/ wv_agricultural_and_forestry_experiment_station_bulletins

\section{Digital Commons Citation}

Howard, Charles D., "Occurrence of barium in the Ohio Valley brines and its relation to stock poisoning" (1906). West Virginia Agricultural and Forestry Experiment Station Bulletins. 103.

https://researchrepository.wvu.edu/wv_agricultural_and_forestry_experiment_station_bulletins/103 @ WVU. It has been accepted for inclusion in West Virginia Agricultural and Forestry Experiment Station Bulletins by an authorized administrator of The Research Repository @ WVU. For more information, please contact ian.harmon@mail.wvu.edu. 
$+$ 



\section{WEST VIRGINIA UNIVERSITY \\ AGRICULTURAL EXPERIMENT STATION \\ MORGANTOWN, W. VA.}

\section{Occurrence of Barium in the Ohio Valley Brines AND ITS}

\section{Relation to Stock Poisoning.}

By C. D. HOWARD, Associate Chemist.

[The Bulletins and Reports of this Station will be mailed free to any citizen of West Virginia upon written application. Address Director of Agricultural Experiment Station, Morgantown, W. Va.] 


\section{THE REGENTS OF THE WEST VIRGINIA UNIVERSITY}

Name of Regent.

P. O. Address.

Hon. C. M. BabB ............... Falls, W. Va.

Hon. J. B. FINLEY . . . . . . . . . . . . Parkersburg, W. Va.

Hon. D. C. Gallaher ................ Charleston, W. Va.

Hon. E. M. Grant.................. Morgantown, W. Va.

Hon. C. E. Haworth............... Huntington, W. Va.

Hon. C. P. McNeli................Wheeling, W. Va.

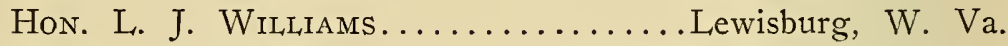

Hon. T. P. Jacobs.............. New Martinsville, W. Va.

Hon. J. R. TrotTer................ Buckhannon, W. Va.

President of the Board of Regents........... J. R. TROTTER President of the University............. B. B. Purinton

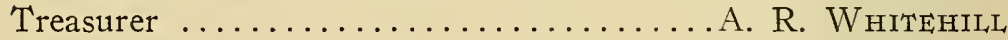
Auditor.$\ldots \ldots \ldots \ldots \ldots \ldots \ldots \ldots \ldots \ldots \ldots \ldots \ldots \ldots \ldots \ldots$. J. White

\section{STATION STAFF}

JAMES H. STEWART, A. M........ Director and Agriculturist BERT H. Hite, M. S........... Vice Director and Chemist

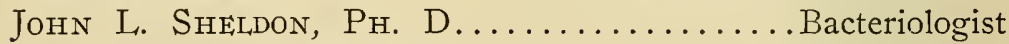
W. E. Rumsey, B. S. Agr........... Entomologist in Charge Horace ATwood, M. S. Agr............Assistant Agriculturist T. C. Johnson, M. S..............Associate Horticulturist Frank B. Kunst...................Assistant Chemist C. S. Forkum, B. S.................. Assistant Chemist

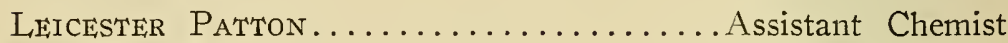

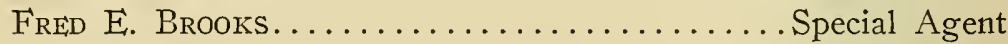
W. J. WHIтЕ......................... Bookkeeper

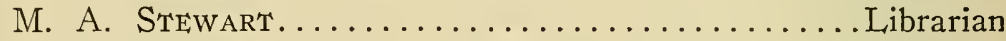

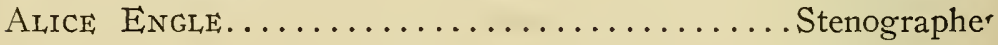




\section{OCCURRENCE OF BARIUM IN THE OHIO VALLEY BRINES}

\section{RELATION TO STOCK POISONING}

\section{*By C. D. Howard, Associate Chemist.}

During the spring of 1899 a resident of this State forwarded the Station for examination a sample of cattle salt supposed to contain some form of poison. His ground for suspicion was the sudden deaths of several mules which had partaken of the salt in question. A search for the commoner poisons in this sample resulted negatively and a report was accordingly made to the effect that death had probably been due to other causes.

At that time a considerable quantity of what was assumed as being choride of calcium was observed in the salt sample but such quantity was not considered sufficient to have been responsible for the loss reported. Several years later, as a result of some brine analyses made by the writer, it occurred to him to examine the sample for barium, with the result that the constituent supposed to be lime proved to consist almost wholly of chloride of barium.

In May of the same year there was brought to the Station the viscera of two horses, the deaths of which were suspected of having been due to arsenic poisoning, the symptoms given corresponding fairly well with the action of this substance. The stomach lining and kidneys were found to be inflamed while the contained fluids presented a muddy brown appearance. No arsenic was detectable. A qualitative examination of the fluids showed

*Resigned July, 1905, to accept position of Chief Chemist of New Hampshire State Board of Health. 
the presence of considerable quantities of sodium salts and, as in the case above cited, the precipitant for the lime group gave an especially marked reaction. While the latter circumstance afforded ground for suspicion it was found difficult to explain how the animals could have ingested any great quantities of lime compounds beyond what might be present in the salt fed them.

During the past few years a number of other cases of wholesale stock poisoning in this State have been brought to the Station's attention. In two cases conspicuous evidence was found of arsenical poisoning with malicious intent. In another case several cows died as the result of drinking water from a trough in which salt-peter sacks had been soaked. Further instances have occurred where some form of poisoning was strongly suspected but was not proven. In how many of these, poisonous salt residues may have been responsible, cannot be told.

In I89I several cases of stock poisoning were investigated by the Kentucky Station. (Kentucky Station Report I89I, page 20), In one instance the deaths of several animals belonging to the same individual were traceable to Paris green. A number of other cases, however, were investigated in which no poison was found, although mention is made of the examination of two samples of salt for arsenic. As the brines of Kentucky are of similar character to those of West Virginia and of Eastern Ohio, this instance may or may not have some significance in the present connection.

\section{Occurrence of Barium Chloride in the Ohio Valley Brines.}

The distinguishing characteristic of the salt made from the Ohio valley brines is its ready solubility, it being known therefore as "soft" salt. That produced in the New York and Michigan districts, on account of its content of gypsum, dissolves much more slowly and is known as "hard" salt. The entire absence of gypsum from the Kanawha and Ohio Valley brines and, on this account, the peculiar adaptability of the salt of this section for meat-curing purposes, especially in warm climates, have long been recognized. This salt, in addition to sodium chloride, contains small quantities of the chlorides of calcium and magnesium, bodies 
not only extremely soluble in water, but possessing a decided affinity for moisture. Such salt, therefore, penetrates the meat more rapidly and its effect is more quickly secured than in the case of the northern salts. This may serve to explain to some extent the special antiseptic qualities attributed to the Mest Virginia product.

The co-existence of calcium sulphate (gypsum) and barium chloride in the same solution is chemically impossible on account of the extreme insolubility of the sulphate of barium that would be formed. Most natural waters everywhere contain appreciable quantities of sulphates. In consequence of which any trace of barium in an ordinary water is of comparatively rare occurrence.

Knowledge concerning the existence of notable quantities of barium chloride in the brines of this region, while not altogether lacking seems, nevertheless, to be somewhat vague and limited. Ure's Dictionary (Dictionary of Arts, Manufacturers and Mines, page 742) makes reference to the barium chloride occurring in "the singular brines of the Allegheny Mountains." While other works of general reference give many analyses of brines found in various parts of the world, they contain no allusion to the existence of barium in such.

In many of the analyses on record of the brines in question no mention whatever of barium compounds is made. The salines of West Virginia have not hitherto been studied but analyses of similar brines occurring in Pennsylvania, Eastern Ohio and Kentucky are available. An analysis by Dr. Edward Stierson, of a salt water from the vicinity of Tarentum, Pennsylvania, (American Journal of Science ; (2) XXXIV, 46-47) shows in one thousand parts of brine, $0.006 \mathrm{I} 2$ parts of barium chloride and 0.00378 parts of barium carbonate. Hunt, ("Chemical and Geological Essays," page I2I) in referring to the barium content of the Allegheny River Valley brines, cites Lenny as his authority for the statement that this is "a constant character ( of the brines) in this region over an area of two thousand square miles." Dr. Genth (Preliminary Report of the Mineralogy of Pennsylvania, I874, B. 27) gives the analysis of a "very extraordinary mineral water" from East Clarion, Pennsylvania, showing somewhat less 
than two grains per gallon of barium chloride, and suggests this as being the largest proportion hitherto observed in a water. In the report of 1877 of the Kentucky Geological Survey, Dr. Robert Peter notes the presence of barium chloride in the salt water from Clay county, Eastern Kentucky, "in quantity equal to nearly twenty-three grains to the wine gallon of the water." Dr. Peter also found barium in smaller quantities in a brine from Meade county, northwestern Kentucky.

Following is an analysis made by the writer during January, I905, of a sample of brine from Malden, West Virginia :

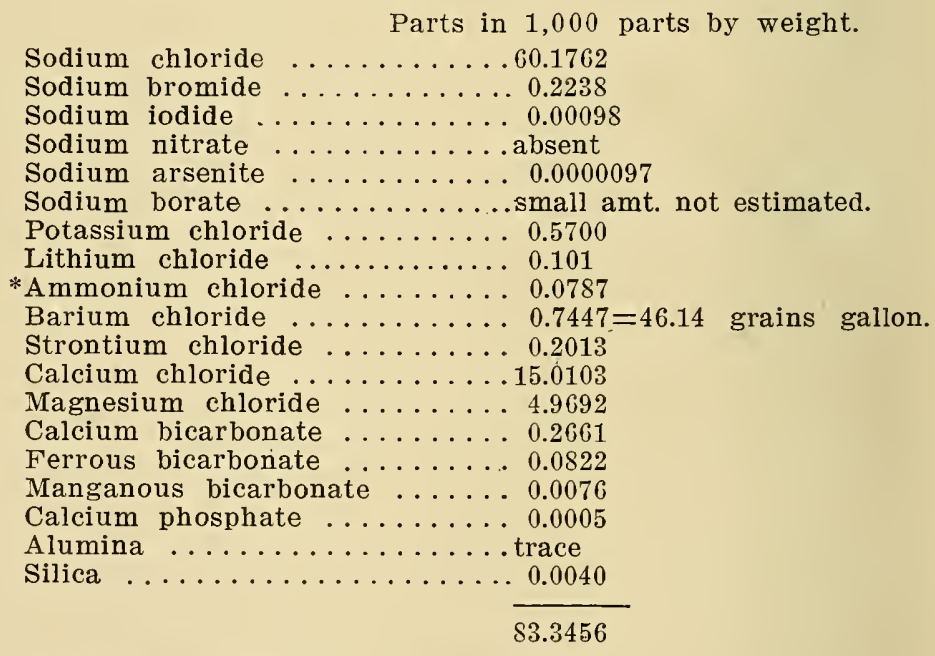

Specific gravity at $15.5^{\circ} \mathrm{C} 1.062 \mathrm{~S}$

\footnotetext{
*Attention is called to the extraordinary large proportions of ammonium chloride occurring in all the brines of this section. The writer has observed this to be a constant phenomenon of both muriated and alkaline waters throughout the coal fields. In this connection it is interesting to note a report made some years ago concerning the ejection of pieces of ammonium carbonate from a newly bored gas well in the Pennsylvania field. (Ford's report to Edgar Thompson Steel Co.)
} 
A sample of brine received from Hartford City in March, I904, gave the following analytical results:

Parts in 1,000 parts by weight.

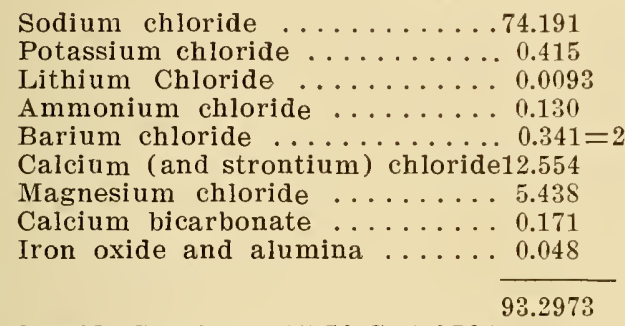

Specific Gravity at $15.5^{\circ}$ C. 10732

A special search for the elements, calcium and rubidium, in this sample resulted negatively.

The next analysis is a weak brine from Webster Springs, Webster County, received in September, I903:

Parts in 1,000 .

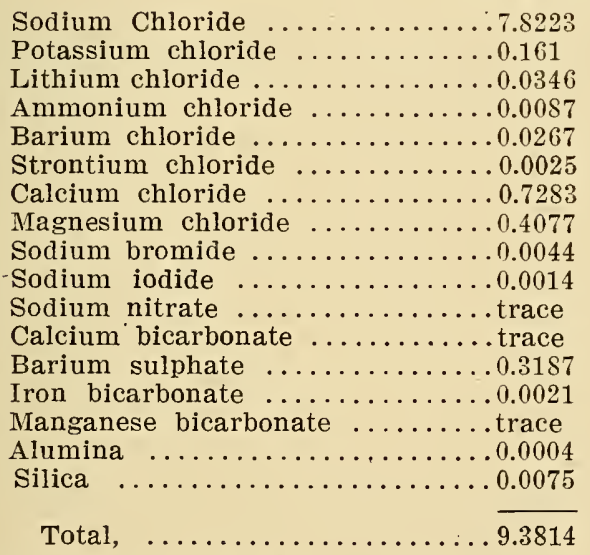

Specific gravity at $15.5^{\circ}$ C. 1.0069

The above differs from the other salt waters of this vicinity (Webster Springs) in the remarkable absence of any trace of sulphuretted hydrogen or sulphides. This phenomenon (care- 
fully observed at the well is doubtless attributable to subterranean re-oxidation of the sulphur originally resulting from the reduction of the sulphate by organic matter (hydrocarbons).

An effort was made to obtain a sample of the brine at Mercers Salt Works, *in Summers County, but unfortunately this was found impossible at the time as the wells have long been in disuse and are said to be partially filled up. However, the proprietor of these wells, Mr. J. C. Peters, writes that the salt formerly made at this place was in every way similar to the Kanawha salt and that the brine possesses all the characteristics of that near Charleston, no gypsum being apparent. There would seem to be scarcely any room for doubt, therefore, that this brine, as well as that from several borings on the Greenbrier River, and likewise that found in one or two other localities within the State, is all practically identical in composition with that on the Lower Kanawha and Ohio Rivers. Farther to the southwest, however, on the Holston River, in Washington county, Virginia, a brine of entirely different composition is encountered.

The following table contains some recent analysis of brines from localities outside of West Virginia :

*During the Civil War, the brines at Mercers Salt Works became a prominent source of salt supply for the Confederacy. The works were burned by Federal troops in 1863 and were never rebuilt. 


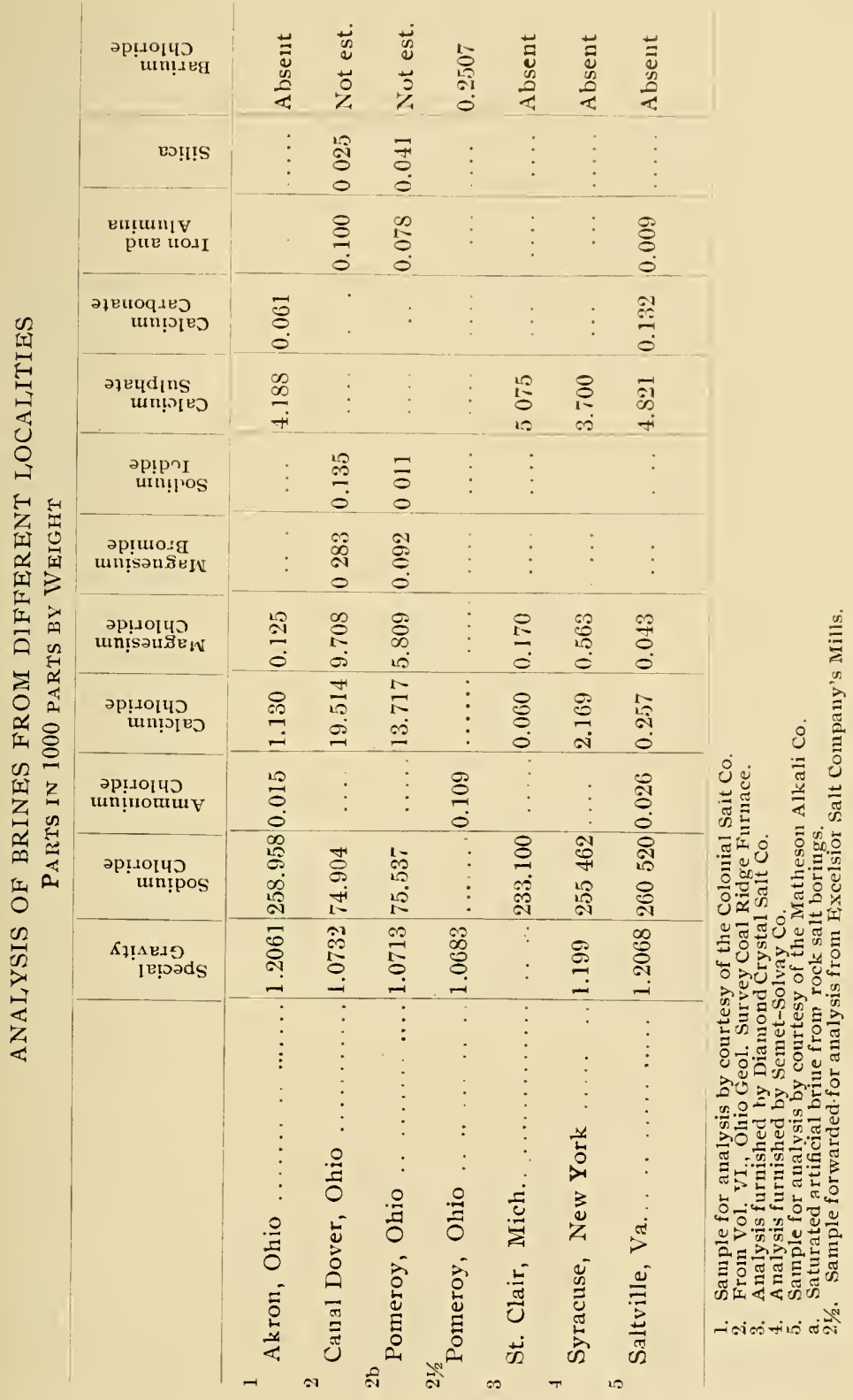




\section{Salt Production in West Virginia.}

The salines of West Virginia are natural brines occurring in the porous sand stone of the sub-carboniverous period. In this respect they differ from those of New York and certain sections of Ohio and Michigan, where the brine is obtained as an artificial solution of the rock salt stratum.

The geological origin of these brines is still a matter of some doubt. The simplest hypothesis that they are merely solutions of lower lying rock salt strata never having as yet been susceptible of any direct proof.

As is evident from the analyses just considered, these brnies are far from being saturated. This fact is mainly responsible for the comparatively insignificant position which the once highly important salt industry of West Virginia has of late years been forced to occupy. In addition to much richer brines Michigan, in the past, has had the advantage of being able to conduct the salt industry as a purely secondary issue in connection with the manufacture of lumber, the waste steam and refuse wood being utilized in the evaporation of the brine.

Until very recently more than nine-tenths of the American production of bromine,-once a remunerative bi-product of the. salt industry-came from West Virginia. At the present day, however, the demand is for a purer bromine than is attainable by the old style process. The new electrolytic method, now in successful operation in the Michigan field, requires for its most economical conduct the brine residues not of one plant but of several, the more, the cheaper the process.

The open kettle process of evaporation is still largely employed in this State, there being, according to the last census, thirty-six kettles in use as against twenty-three grainers. The kettles are large circular vessels of iron, of one hundred to one hundred and twenty-five gallons capacity. A series of these set in masonary is known as a "salt block." In the more economical grainer system most of the evaporation is effected in shallow wooden vats one hundred to one hundred and eighty feet long, from one to two feet deep and traversed logitudinally by copper steam pipes. The waste steam from the grainers is used in a preliminary heating and par- 
tial concentration of the brine in a steam chest and in a series of "mud settlers," wherein carbonic acid gas is removed and the resulting sludge of iron and earthy carbonates settles out. The system is supplied from a large reservoir into which the brine is pumped from the well, and where the same may be chemically treated as the necessity arises.

The crystallization of the salt and its separation from the other compounds in the brine is based upon the fact that sodium chloride is but little more soluble at the boiling than at the ordinary temperature, while the chlorides of potassium, barium and calcium and magnesium are very much more soluble. The latter two salts, remarkable for their solubility, form the clief constituents of the "bitter water," or bittern. A large part of the chloride of barium is also to be found in the residual liquor, although if the separation is pushed very closely much of this compound is carried down in the cheaper grades of salt.

These brines not only contain notable quantities of barium chloride but they are high in calcium and magnesium chlorides. The latter bodies tend to absorb moisture very rapidly and, on this account, the salt made in the Ohio valley possesses a higher moisture content than other salts. It would seem that a preliminary combination treatment of the brine with soda ash and a small amount of sodium sulphate might prove profitable and desirable. Such treatment would insure the complete removal of barium and of most of the lime and magnesium, as well as a return to the brine of a large part of the cost of the precipitants in their equivalent of common salt. Moreover a present not unimportant disadvantage of the local salt - the property of being moist-would be thereby practically eliminated.

\section{Physiorogical Action of Barium Chloride.}

In a recent paper by Fish on "The Effect of Certain Drugs upon Blood Pressure and Cadia Inhibition" (Abstracted in Experiment Station Record XV, II9), the action of various drugs injected intravenously is described. In the case of the horse, "bariuum chloride in doses of twelve grains increased the force of blood pressure. The dog, exhibited an enormous increase of blood pressure and force of the heart action after treat- 
ment with barium chloride. The cardiac and diuretic effests of barium chloride were similar to those of digitalis." Gmelih, a pioneer observer, describes the salts of barium as being "energetic poison, having a special power of destroying the irritability of the voluntary muscles; they act upon the stomach as irritants and also inflame the heart." From Boehms experiments (National Dispensatory) it was shown that in mammals "the injection of a strong solution of barium chloride into the veins immediately excites tonic and clonic convulsions, a discharge of urine and faeces, and general paresis, or, if the dose has been excessive, death in convulsions may ensue."

What is perhaps a somewhat radical view of the toxic action of barium chloride is taken up by Kennedy (Taylor "Poisons") who states that in using this compound as a medicine he has found that "few persons are able to bear the eighth of a grain, that it is analogous to corrosive sublimate, and that an overdose will produce similar effects." The minimum fatal doses on record in the case of man are sixty grains of the carbonate and one hundred grains of the chloride. The medicinal dose varies from as little as one-tenth grain, as recommended by $\mathrm{Da}$ Costa, to one to two grains.

Although the symptoms of poisoning by barium compounds are somewhat similar to those produced by nitrate of potash yet the the latter is apparently much less poisonous, a number of cases being on record where from one to two ounces of this compound have been swallowed without fatal effect.

Calcium chloride, another compound present to a considerable extent in the Ohio Valley brines, is probably analogous, physiologically to barium chloride but its action is much milder. According to the National Disapensatory it is an active irritant and liable to give rise to gastro-intestinal inflammation in excessive doses. Like barium chloride this substance is held by some physiologists to be of distinct therapeutic value. The general dose recommended ranges from ten to twenty grains.

In the cases of stock poisoning from salt reported to this Station the symptoms described were evidences of great pain, perspiration, some frothing at the mouth, diarrhoea and purging, convulsions and death in ten to twenty-four hours. 


$$
\text { Analyses of Salt. }
$$

Following is the analysis of a cattle salt submitted to this department with the request that it be examined for poisons:

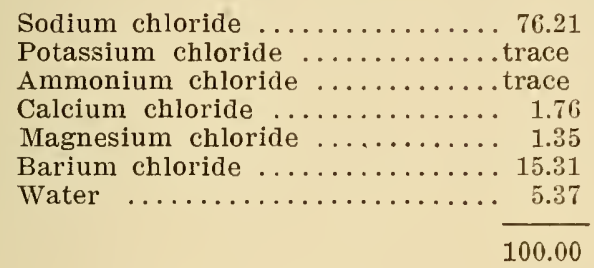

In view of the high content of barium chloride in this salt it would be a matter for surprise if its use for stock feeding was not followed by disastrous results. The above sample, however, is probably an extreme case; this material may possibly have been present in the main lot as an accidental impurity, as it was the buyer's recollection that the same grade had been in use previously without any apparent harmful results. Nevertheless, the undesirability, not to say the danger, in the use of the last separations of salt from these brines is evident.

The analysis next given is of a specimen forwarded for examination to ascertain its fertilizing value.

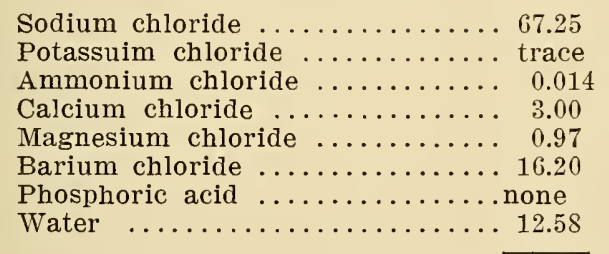

100.014

In the following table are presented analyses of salt received from a dozen localities within the State. The amount of barium chloride, it will be observed, ranges from a harmless trace to $0.88 \%$. Most of the specimens containing gypsum were produced in Northern Ohio. 
Analyses of Salt on Sale in West Virginia.

\begin{tabular}{|c|c|c|c|c|c|c|c|}
\hline 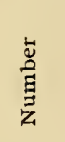 & 窇 & 苞莺 & 苞 & 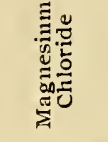 & 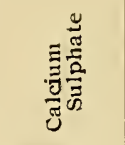 & 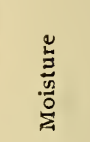 & 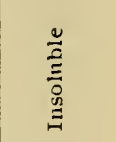 \\
\hline 1 & 98.56 & $\ldots$ & $\ldots \ldots$ & trace & 1.29 & 0.26 & 0.03 \\
\hline 2 & 98.32 & & 0.10 & trace & 1.36 & 0.05 & 0.03 \\
\hline 3 & & 0.34 & & & & & \\
\hline 4 & & & & . & present & & \\
\hline 5 & & . & & & present & & \\
\hline 6 & 96.23 & 0.04 & 1.31 & 0.64 & $\cdots \cdot$ & 1.75 & 0.03 \\
\hline 7 & 96.74 & 0.66 & 1.47 & 0.35 & $\ldots \ldots \ldots$ & 0.75 & 0.03 \\
\hline 81 & 98.56 & 0.00 & 0.21 & trace & 1.00 & 0.15 & 0.08 \\
\hline 9 & 97.61 & trace & 0.81 & 0.40 & ....... & 1.15 & 0.03 \\
\hline 10 & $\ldots$ & 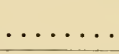 & ... & $\ldots$. & present & & $\ldots \ldots \ldots$ \\
\hline 112 & 98.28 & 0.00 & 0.04 & 0.02 & 1.36 & 0.28 & 0.02 \\
\hline 12 & 97.06 & 0.08 & 0.92 & 0.26 & $\cdots$ & 1.66 & 0.02 \\
\hline 13 & 94.67 & 0.01 & 1.90 & 0.88 & $\ldots \ldots$ & 2.51 & 0.03 \\
\hline 14 & 97.74 & 0.88 & 0.81 & 0.32 & $\cdots$ & 1.22 & 0.03 \\
\hline 15 & 98.21 & 0.05 & 0.74 & 0.30 & 10. & 0.65 & 0.05 \\
\hline 16 & 98.02 & 0.05 & 0.84 & 0.24 & $\ldots$ & 0.80 & 0.05 \\
\hline $17^{3}$ & 95.93 & 0.00 & 1.42 & 0.04 & $1 \cdots$ & 1.28 & $0.06 \mathrm{x}$ \\
\hline
\end{tabular}

1 Claimed to have been manufactured from Pomeroy brine. If correct the latter must have received a preliminary treatment with an alkaline sulphate.

2 Claimed to have been manufactured in West Virginia (?)

3 This sample also contained $1.27 \%$ of earthy carbonates indicating use of soda ash in its preparation.

$\mathrm{x}$ Insoluble in acid. 
Antiseptic Properties of Cacium and Barium Chlorides.

r. Ten c. c. of fresh, skimmed milk was placed in cottonplugged and sterilized test tubes. The quantities of the salts indicated below were added and the tubes were allowed to remain at about $70^{\circ} \mathrm{Fh}$. for seventy-eight hours. As it is well known that a small amount of common salt favors rather than retards bacterial growth, a quantity of sodium chloride equivalent to $\mathrm{x} \%$ was also added to tubes Nos. 7 to 22 , inclusive. All of these salts were practically neutral in reaction.

\section{Condition after \\ is hours.}

C. C. of $\frac{N}{I 0}$

alkali required

for 10 c. c. mill

No. 1. Plain blank

No. 2.

Solid $\ldots \ldots \ldots \ldots \ldots \ldots \ldots .69 .6$

No. $3.1 \%$ Sodium chloride

No. $4.1 \%$

No. 5. $3 \%$

No. 6. $3 \%$ " "

No. 7. $1 / 2 \%$ Calcium chloride

No. 8. $1 / 2 \%$

No. $9.1 \%$

No. $10.1 \%$

No. $11.3 \%$

No. $12.3 \%$

No. $13.1 / 2 \%$ Barium "

No. $14.1 / 2 \%$

No. $15.1 \%$

No. $16.1 \%$

No. $17.3 \%$

No. $18.3 \%$

, " "

" " "

“ 4

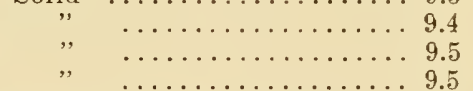

Neariy normal fluidity.... 8.6

Nearly normal fluidity..... 8.4

Solid .................

No. 19. $1-20 \%$ Corrosive Sublimate, Normal odor and fiuidity 2.4

No. 20. $1-20 \%$

No. 21. $1-10 \%$

No. $22.1-20 \%$

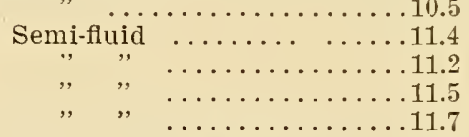

Nearly normal fluidity ....10.2

$\ldots 10.3$

$\ldots 10.2$

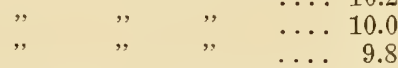

" $\quad, \quad, \quad \ldots .969 .8$

With the exception of tubes 19 to 22 inclusive, all showed a slightly sour odor.

This experiment was repeated on another sample of milk with perfectly analogous results. The addition of sodium chloride to the extent of $3 \%$ checks fermentation somewhat and almost entirely prevents coagulation of the casein* On the other hand

*That the addition of common salt to the extent of $5 \%$ serves to entirely check the coagulative action of rennet has been observed by the IVisconsin station. (Wisconsin Station Report, 1898.) 
addition of either calcium or barium chloride (with I\% sodium chloride) tends to increase the amount of fermentation (as indicated by the acidity) over what occurs without such addition, notwithstanding that the coagulation of casein is checked. The tendency to an increased acidity is greater with calcium chloride than with barium chloride.

II. Fresh bouillon (containing no sugar) was inoculated from the deposit on a water filter and ten cc. placed in sterilized test tubes containing sodium, calcium and barium chlorides as below indicated. After standing at room temperature for seventytwo hours the following observations were made:

Blank Heavy growth

Markedly putrefactive odor.

$1 \%$ Sodium chloride Considerable growth

$3 \%$ Calcium chloride

Slight growth

$3 \%$ " chloride

$1 \%$ Barium " . " , ,

$3 \%$ " "

III. The above experiment was repeated using fermentation tubes and bouillon containing I $\%$ of milk sugar. After two weeks the tubes containing $3 \%$ of sodium chloride showed no putrefactive odor and no gas had been generated. The $2 \%$ barium and calcium tubes both showed marked putrefaction, with a gas development of about 10\%. In the case of the $3 \%$ barium and calcium tubes, putrefaction had set in, about $5 \%$ of gas having been evolved. 
These results, as far as they go, would seem to point to the following conclusions:

The presence of calcium chloride in appreciable quantities in a dairy salt is objectionable, aside from the question of taste.

While in itself possessing at least no greater antiseptic value than sodium chloride for meat-curing, the occurrence in small quantities of calcium chloride in common salt used for this purpose is probably advantageous on account of its indirect action. For use in this connection the presence of calcium chloride in a salt is unquestionably to be preferred to a like percentage of calcium sulphate, on account of the latter's tendency to cake and iarden on the meat and thus hinder penetration.

Notwithstanding the moderate approach in the similarity of the nhysiological action of barium chloride to that of corrosive sublin nate the former compound possesses none of the pronounced antiscptic qualities exhibited by the latter. 
